\title{
Affective Disposition, Thinking Styles, Neuroticism and Life Satisfaction*
}

\author{
Disposición afectiva, estilos de pensamiento, \\ neuroticismo y satisfacción vital
}

Recibido: febrero 2 de 2011 | Revisado: octubre 10 de 2011 | Aceptado: junio 28 de 2012

\author{
CRISTIAN ZANON ** \\ Claudio Simon Hutz \\ Universidade Federal do Rio Grande do Sul, \\ Porto Alegre, Brasil
}

doi:10.11144/Javeriana.UPSY12-2.adts

Para citar este artículo: Zanon, C. \& Hutz, C. S. (2013). Affective disposition, thinking styles, neuroticism and life satisfaction. Universitas Psychologica,12(2), 403-411.

* This research is part of the first author's thesis under the supervision of the second author. This work was supported by CAPES funding.

** Universidade Federal do Rio Grande do Sul, Institute of Psychology, Post graduate Program in Psychology. Ramiro Barcelos, 2600, sala 101. CEP 90035-003. Bairro Santa Cecília, Porto Alegre/RS. E-mails: cristianzanon@yahoo.com.br, claudio. hutz@terra.com.br

\begin{abstract}
A B S T R A C T
The way in which positive and negative affects are perceived may be associated with a distinct pattern of behaviors and attitudes. The aim of this study was to evaluate the relationship between various combinations of affections and gender along with tendencies towards neuroticism, rumination, reflection, and life satisfaction. The participants were 348 students, who answered the questionnaire in groups. The euphoric group showed the highest scores of life satisfaction and emotional stability, while the dysphoric group presented the lowest scores. The emotional and apathetic groups showed no significant differences in relation to life satisfaction, depression, anxiety and vulnerability. From these results, it can be assumed that positive affect can lessen the impact that negative affect has on the development of vulnerability and other psychopathological symptoms. Interventions based on positive affect increase might be efficient to prevent vulnerability. Key words authors

Positive affect, negative affect, neuroticism, life satisfaction.

Key words plus

Quantitative Research, Psychometry, Emotion.

\section{RESUMEN}

La forma en que los afectos positivos y negativos son percibidos puede estar asociada con un patrón diferenciado de comportamientos y actitudes. El objetivo de este estudio fue evaluar la relación entre varias combinaciones de afectos y género, junto con tendencias hacia el neuroticismo, la rumiación, la reflexión y la satisfacción vital. Los participantes fueron 348 estudiantes que respondieron al cuestionario en grupos. El grupo eufórico mostró las puntuaciones más altas en satisfacción vital y estabilidad emocional, mientras que el grupo disfórico presentó las puntuaciones más bajas. Los grupos emocional y apático no mostraron diferencias significativas en relación con la satisfacción vital, depresión, ansiedad y vulnerabilidad. A partir de estos resultados, se puede suponer que el afecto positivo puede reducir el impacto que el afecto negativo tiene en el desarrollo de la vulnerabilidad y de otros síntomas psicopatológicos. Intervenciones que se basan en el aumento de afecto positivo podrían ser eficientes para prevenir la vulnerabilidad.

Palabras clave autores

afecto positivo, afecto negativo, neuroticismo, satisfacción vital.

Palabras clave descriptores

Investigación cuantitativa, psicometría, emoción.
\end{abstract}




\section{Introduction}

Positive and negative affects are within the emotional dimension of subjective well-being (Diener, Scollon \& Lucas, 2003), characterized by the frequency and intensity of emotions and feelings that an individual experiences as either pleasant or unpleasant (Lyubomirsky, King \& Diener, 2005). In turn, the affective disposition, or the way in which people perceive positive and negative affects, may be associated with a distinct pattern of behaviors and attitudes. The objective of this study, therefore, is to evaluate the relationship between different combinations of positive and negative affects (AD: affective disposition) with Neuroticism (and its facets), rumination, reflection, life satisfaction and gender.

Individuals with high scores of positive affect (PA) experience frequent and intense episodes of pleasure. Furthermore, they consider themselves happy, enthusiastic, and confident (Lyubomirsky et al., 2005). Conversely, those subjects with high levels of negative affect (NA) experience repeated episodes of intense displeasure (Watson, 2005). Generally, these people perceive themselves as sad, discouraged, and anxious. According to Naragon and Watson (2009), low levels of positive affect are among the symptoms of several disorders, such as social phobia, agoraphobia, posttraumatic stress disorder, schizophrenia, eating disorders and substance abuse disorders, amongst others.

Some studies suggest that positive and negative affects are independent factors (Bradburn, 1969; Diener \& Emmons, 1985). Adopting this view one assumes that both affects can coexist at the same moment without necessarily canceling each other out. Based on this idea, it is then theoretically possible to increase the levels of positive affect without necessarily reducing the levels of negative affect. This has direct clinical implications, since a therapist can focus its intervention on strengthening and developing those healthy aspects of patients to increase their well-being, as opposed to focusing primarily on reducing their levels of negative affect (Seligman, 2005; Watson, 2005).
There is evidence that different combinations of affect are associated with several indicators (Norlander, Bood \& Archer, 2002). Some studies found that individuals with high scores of positive affect and low scores of negative affect have greater emotional stability (Karlsson \& Archer, 2007) and a healthier psychological profile (Bood, Archer \& Norlander, 2004). On the other hand, individuals with high scores of negative affect and low positive affect scores have shown higher rates of anxiety, depression and stress, along with lower optimism scores (Arntén, Jansson \& Archer, 2008).

It has also been found that individuals with high scores of both positive and negative affect have higher levels of energy and optimism, but also anxiety, depression and stress (Arntén et al., 2008). Finally, subjects with low scores of both positive affect and negative affect have lower levels of anxiety and depression compared to subjects with high scores of positive and negative affect, but they also have lower scores of optimism and energy than individuals with high positive affect and low negative affect (Arntén et al., 2008). Since different combinations of affect are related to different psychopathological indicators, it is possible that they also have varied configurations of neuroticism, thinking styles and life satisfaction.

\section{Neuroticism, Thinking Styles, and Life Satisfaction}

Neuroticism (emotional maladjustment) is a factor of the Big Five model (McCrae \& John, 1992) composed, in Brazil, of four facets (vulnerability, psychosocial disadjustment, anxiety, and depression) that categorize personality traits as hopelessness, irritability and hostility (Hutz \& Nunes, 2001). These four facets slightly differ from the facets found on the most used test around the world (NEO-PI-R: Costa \& McCrae, 1992) because in the Brazilian test the items did not load on six components and so the most appropriate solution was kept. The degree and frequency with which the features highlighted by these facets manifest themselves in people, determine the prevalence of each trait. Individuals with high scores of Neuroticism are typically anx- 
ious, they have frequent changes in mood, tend to suffer from psychosomatic disorders, and have very intense reactions to stimuli. Moreover, there is evidence that Neuroticism is positively correlated with rumination and negative affect, and negatively related to positive affect and life satisfaction (Deneve \& Cooper, 1998; Steel, Schmidt \& Shultz 2008).

Rumination and reflection are two distinct ways of thinking about oneself, and both are present in all people to a greater or lesser degree (Trapnell \& Campbell, 1999). While rumination would be an incongruent and unproductive way in which to think about oneself, it is usually characterized by repetitive and persistent thoughts (Nolen-Hoeksema, 1991), this constant reflection can lead to a more accurate knowledge of self, and thusly a superior problem solving ability (Trapnell \& Campbell, 1999). Evidence shows that ruminative thinking is associated with depression (Papageorgiou \& Wells, 2004), anxiety (Muris, Roelofs, Rassin, Franken \& Mayer, 2005), hopelessness (Lyubomirsky, Caldwell $\&$ Nolen-Hoeksema, 1998) and negative affect (Trapnell \& Campbell, 1999). In turn, it is plausible that a reflective thinking mitigates the psychological distress and acts as a protective factor against mental illness, since it could dampen the negative impact of rumination (Joireman, 2004).

Finally, life satisfaction, the cognitive component expressed as a sense of well-being, is characterized by an individual's perception of how happy they are with their life (Diener, Lucas \& Oishi, 2005). Generally, life satisfaction is positively correlated with self-esteem, and negatively to Neuroticism (Deneve \& Cooper, 1998). Moreover, the literature suggests that people with high levels of life satisfaction often experience high positive affect and lower levels of negative affect. However, the levels of life satisfaction in individuals with both high positive affect and high negative affects are not very known, as is the same on individuals with low scores in both affects (see, Grueber, Maus \& Tamis, 2011, for a perspective on patients with bipolar disorders).

This study was undertaken to advance the understanding of positive and negative affects, as well as its relationship with personality traits, thinking styles and life satisfaction. The results of this study
TABLE 1

Affective Disposition

\begin{tabular}{lcc}
\hline \multicolumn{1}{c}{ Groups } & \multicolumn{2}{c}{ Affects } \\
\hline \multirow{3}{*}{ Dysphoric } & positive affect & negative affect \\
\cline { 2 - 3 } Euphoric & $\downarrow$ & $\uparrow$ \\
Emotional & $\uparrow$ & $\downarrow$ \\
Apathetic & $\uparrow$ & $\uparrow$ \\
\hline
\end{tabular}

*the symbol " $\uparrow$ " represents high level of the construct and the symbol " $\downarrow$ "represents low level of the construct.

Source: own work

may be relevant to the development of new clinical interventions, which focus on the development of positive affect.

To assess the relationship between the four possible combinations of positive and negative affect (affective disposition), as presented in Table 1, with the other variables mentioned earlier, this study aims to evaluate the differences in the averages of Neuroticism, vulnerability, psychosocial disturbance, anxiety, depression, rumination, reflection and life satisfaction within the four affection groups. Once the dysphoric participant have high levels of negative affect and low levels of positive affect, it might be expected to find these people with high levels of Neuroticism, vulnerability, psychosocial disturbance, anxiety, depression, rumination, and with low levels of life satisfaction. On the other side, euphoric participants are likely to present high levels of life satisfaction, and low levels of Neuroticism, vulnerability, psychosocial disturbance, anxiety, depression, rumination. Emotional and Apathetic groups will probably show differences in the way that they experience their lives and symptoms, however, no clear clue is hypothesized once positive and negative affect might not buffer each other. Another objective was to verify possible gender differences.

\section{Method}

\section{Participants}

The participants were 348 university students (48.5\% women and $51.5 \%$ men) between the 
ages of 16 and $55(M=20$ years, $S D=3.6)$. Over $95 \%$ of the sample is composed by Caucasians. The participants were selected based on convenience and their participation in the study was voluntary.

\section{Instruments}

Positive Affect and Negative Affect: These variables were measured using the Positive and Negative Affect Scale (PANAS: Watson, Clark \& Tellegen, 1988; adapted to Portuguese by Giacomoni \& Hutz, 1997). This scale consists of two orthogonal factors: positive affect and negative affect. Both have good internal consistency (Cronbach Alphas of 0.88 and 0.86 , respectively). Each factor consists of 20 adjectives representing the various moods and emotions of subjects, such as 'nice', 'cautious', 'distressed', and 'impatient'. Each adjective is rated by the participants on a 5-point Likert scale.

Life Satisfaction: This quality was measured using the Life Satisfaction Scale (ESV: Pavot \& Diener, 1993; adapted to Portuguese by Hutz, Bardagi, Souza \& Sternert, 2009), which is composed of five statements such as: "My life is close to my ideal." The Brazilian adaptation has good internal consistency (Cronbach's alpha $=0.91)$.

Neuroticism Factor Scale (NFS: Hutz \& Nunes, 2001): A self reporting instrument modeled on the Big Five, this scale allows for a fast and objective evaluation of the dimension of human personality known as Neuroticism. The scale is comprised of 82 items divided into four subscales: Vulnerability, Psychosocial Maladjustment, Anxiety, and Depression. Moreover, the instrument provides a total score for the Neuroticism factor, which is derived from the sum of standardized scores of these facets. Items in the NFS were constructed in the form of sentences that describe the attitudes, beliefs and feelings of participants. Examples of the items include: "I often go through periods where I get extremely irritable, and I am annoyed with the smallest things," and "I don't do the things I want to do for fear of being criticized by others." The NFS showed adequate internal consistency - Cronbach's alpha - ranging from 0.88 to 0.92 .
Rumination and Reflection Questionnaire (RRQ: Trapnell \& Campbell, 1999; adapted to Portuguese by Zanon \& Teixeira, 2006): Composed of two scales with 12 items each, this test was designed to evaluate how individuals engage in ruminative and reflective thoughts. Examples of items include: "I spend a good time recalling embarrassing moments or frustrations I've passed through;" "Long after a disagreement or argument is over, my thoughts remain focused on what happened;" and "I always seem to be brooding in my mind about the things I recently said or did." Evidence (Zanon \& Teixeira, 2006; Zanon \& Hutz, 2009) indicates that the RRQ has factorial validity and a satisfactory internal consistency for use within the Brazilian universities (Cronbach's alpha $=0.87$ for both scales).

\section{Procedure}

The participants responded collectively to the questionnaires from within their classrooms. Beforehand, the students were informed that the participation in the study was voluntary, and that all the information shared would remain confidential.

The participants were asked to carefully read the questions and respond to items according to their personal feelings. Data collection was performed in a single session for each class of students and the total time taken to complete the test was approximately 45 minutes.

\section{Results}

Four groups were created from combinations of affect (as presented in Table 1), and determined by the participants' positive and negative affects scores. Those subjects with scores above the mean are considered high in positive and negative, and those who scored below average were considered low in affect. The mean score for positive affect was 65 , and 45 for negative affect. The means and standard deviations of the dependent variables are presented in Table 2.

One Pillai's MANOVA (2 X 4 Factorial design) was conducted with independent variables of the affective disposition (AD) and gender, and 
the four dependent facet variables of Neurotic dimension: vulnerability, psychosocial disturbance, anxiety, and depression. There was no effect from an interaction between the independent variables. The analysis showed significant differences among groups of affective disposition and gender differences. An analysis for each of the facets showed the following results:

Vulnerability: There was a significant difference between the four $\operatorname{AD}$ groups $(F(3,317)=19.7$, $p<0.01)$. Descriptive analysis and post hoc tests (Scheffe) revealed that the dysphoric group had the highest average vulnerability, significantly higher than the euphoric group $(d=1.0)$, the emotional group $(d=0.4)$, and the apathetic group $(d=0.7)$. The " $\mathrm{d}$ " is an estimate of effect size in terms of percentage of standard deviation (Cohen, 1988). Other groups that showed significant differences were the euphoric and emotional groups $(d=0.5)$. No significant difference was found for gender $(F(1,317)<1)$.

Psychosocial Maladjustment: There was no significant difference among the four groups AD $(F(3,317)=<1)$, but there was a significant difference in regards to gender $(\mathrm{F}(1,317)=4.81$, $p<0.03)$. Men $(M=31.64, S D=18.4)$ had a higher average of inconsistency than women $(\mathrm{M}=26.1$, $S D=16.8, d=0.5$ ).

Anxiety: There was a significant difference among the four groups $\operatorname{AD}(F(3,317)=14.0$, $p<0.01$ ]. Descriptive analysis and post hoc tests (Scheffe) revealed that the dysphoric group had the highest average anxiety, which differed significantly from the euphoric group $(d=0.7)$ and the apathetic group $(d=0.8)$. There was also a significant difference in terms of gender $(F(1,317)=6.0$, $p<0.02)$. Women $(M=80.7, S D=25.4)$ had a higher average for anxiety than men $(M=74.1$, $\mathrm{SD}=25.4, d=0.3)$.

Depression: There was a significant difference among the four groups $\operatorname{AD}(F(3,317)=11.9, p$ $<0.01)$. Descriptive analysis and post hoc tests (Scheffe) revealed that the dysphoric group had the highest average of depression, significantly higher than the averages for the euphoric group $(d=0.7)$ and the apathetic group $(d=0.6)$. There was no significant difference in terms of gender $(F(1,317)$ $=3.21, p>0.05$ ).

Two-way ANOVA's were performed for independent variables of the four affect groups and gender. The dependent variables were: neuroticism, rumination, reflection, life satisfaction, positive affect and negative affect.

Neuroticism: The value of the variable scores is represented by a $T$ score because the value for Neuroticism is found by adding the standardized scores of Vulnerability, Psychosocial Maladjustment, Anxiety and Depression. A significant difference was observed among the four groups $\mathrm{AD}$ $(F(3,328)=138.9, p<0.01)$. Descriptive analysis and post hoc tests (Scheffe) revealed that the dysphoric group had the highest average for neuroticism, significantly higher than in the euphoric $(d=0.8)$ and apathetic groups $(d=0.7)$. Other groups that differed significantly were the euphoric and emotional groups $(d=0.5)$, and the emotional and apathetic groups $(d=0.4)$. There was a significant interaction between groups $\mathrm{AD}$ and gender $(F(3,317)<1)$, but no significant differences between the sexes $(F(1,317)<1)$.

Rumination: There was a significant difference between the $\operatorname{AD}$ groups $(F(3,328)=24.2$, $p<0.001)$. Descriptive analysis and post hoc tests (Scheffe) revealed that the dysphoric group had the highest average rumination, significantly higher than the euphoric group $(d=1.0)$ and the apathetic group $(d=0.8)$. Other groups that differed significantly were the euphoric and emotional groups $(d=0.7)$ and the emotional and apathetic groups $(d=0.6)$. There was a significant interaction between the AD groups and gender $(F(3,328) p<1)$, but no significant differences between the sexes $(F(1,328) p<1)$.

Reflection: There was no significant difference between the $\operatorname{AD}$ groups $(F(3,338)=1.89$, $p>0.05)$. However, there were significant differences observed in terms of gender $(\mathrm{F}(1,338)=6.70$, $p<0.02]$. Men $(M=40.3, S D=10.6)$ had higher averages of reflection than women $(M=37.1$, $S D=9.9, d=0.3)$. No significant interaction between the $\mathrm{AD}$ groups and sex $(F(3,338)=1.89$, $p>0.05)$ was observed. 
Life satisfaction: There was a significant difference between the $\operatorname{AD}$ groups $(F(3,346)=20.89$, $p<0.001$ ]. Descriptive analysis and post hoc tests (Scheffe) revealed that the euphoric group had the highest average life satisfaction, significantly higher than the dysphoric group $(d=0.9)$, the emotional group $(d=0.4)$ and the apathetic group $(d=0.7)$. Furthermore, the apathetic and dysphoric groups differ significantly $(d=0.5)$. There was also a significant difference in terms of gender $(F(1,346)=6.71 p<0.02)$. Women $(M=26.2$, $\mathrm{SD}=5.3, d=0.2)$ had an average life satisfaction higher than that of men $(M=25, S D=6.1)$. There was a significant interaction between affective disposition and gender $(F(3,346) p<1)$.

\section{Discussion}

This study aimed to evaluate how different combinations of affect are related to personality traits, thinking styles, life satisfaction and gender. In the end, the results showed that the euphoric group had the lowest average for Neuroticism, vulnerability, anxiety, depression and rumination. In addition, individuals in this group had the highest average life satisfaction. These results suggest that the subjects with high scores of positive affect and low scores of negative affect are generally satisfied with their lives. Furthermore, these participants have few personality traits that resemble symptoms of depression or anxiety disorders. In short, this group is the most emotionally stable and content.

On the other hand, dysphoric participants showed the highest average Neuroticism, vulnerability, anxiety, depression, and rumination, with the lowest average life satisfaction. These individuals were the most dissatisfied with their lives, and also possessed personality characteristics that are related to symptoms of anxiety disorders and depression. The magnitude of differences in averages for neuroticism between the dysphoric group and the euphoric groups indicates that each one has a distinct psychological profile. These results are similar to those found by Norlander, Bood, and Johansson (2005), and Arntén, Jansson and Archer (2008).
The differences between the dysphoric and emotional groups suggest that high scores of positive affect can alleviate the effects of negative affect on the development of vulnerability. With this in mind, the results revealed that the emotional and apathetic groups had no statistically significant differences in relation to life satisfaction, depression, anxiety and vulnerability. These results reinforce the notion that positive affect can, in some ways, minimize the impacts that negative affect has on a sense of well-being and its potential to develop into psychopathological symptoms. It is important to note, however, that this supposition is only true in relation to vulnerability, since there were no significant differences observed between the dysphoric and the emotional groups beyond the variables discussed.

The differences between the emotional and apathetic groups, in relation to Neuroticism and rumination, suggest that the individuals who frequently experience negative affect (occasionally at the same time as positive affect) ruminate more and have greater emotional instability than those who do not experience positive or negative affect. It is possible that subjects who develop traits of Neuroticism, and who frequently experience negative affect, may be predisposed to rumination (Roberts, Gilboa \& Gotlib, 1998). In this case, high scores of positive affect seem somewhat relevant for those subjects with respect to rumination and show signs of emotional stability. People who ruminate often and have high scores of Neuroticism, perhaps, would benefit more from therapy that focuses on reducing rumination (Lyubomirsky $\&$ Tkach, 2004).

Neither psychosocial maladjustment nor reflection showed any statistically significant change in relation to affective disposition. In terms of psychosocial disturbance, the data suggests that the trends in violating social norms, alcohol abuse, partaking in risky sexual behavior, among other practices, are not associated with the levels of positive or negative affect. Other factors, such as cultural values or peer groups, may help to determine those behaviors. There is also no evidence that ties different combinations of affection to reflection. 
Although reflective subjects feel more satisfied because they are more adaptable and have a better problem solving the ability, it is possible that these people possess a more pessimistic outlook on the world (Trapnell \& Campbell, 1999) and suffer because of it. Therefore, this reflection does not seem to be directly related to affect.

Regarding gender differences, women were found to have had the higher averages of anxiety and life satisfaction, while men showed higher averages of psychosocial disturbance and reflection. Except for psychosocial maladjustment $(d=0.5)$, other differences were shown to be minimal $(d=0.2$ or 0.3$)$ between men and women, representing a small magnitude of difference. Indeed, the literature supports the findings that women have higher averages of anxiety and that men have higher scores of psychosocial disturbance (Hutz \& Nunes, 2001). Studies (Jose \& Brown, 2008; Nolen-Hoeksema \& Jackson, 2001) suggest that women have higher levels of depression and rumination than men, which was not observed in this study. It is possible that this result is due to some idiosyncrasies within the sample.

In sum, these findings corroborate part of the Positive Psychology suppositions that emphasize in the development of positive aspects, virtues, and strengths, instead of just trying to impair negative ones. It might be of great value to promote mental health (Seligman, 2005). More specifically, to have high levels of positive affect can somehow alleviate deleterious effects caused by negative affect on vulnerability. Considering that vulnerability may be an entrance door to the exacerbation of symptoms and psychopathologies, the findings of this study suggest that interventions designed to increase positive affects might be efficient to prevent vulnerability. These results are preliminary and should be tested on specific interventionbased research.

The main limitation of this study is the sample studied. The participants were university students from only one region of Brazil. It is a homogeneous and non-representative sample. Therefore, these results should be corroborated in more heterogeneous and more representative samples.

\section{References}

Arntén, A. A. -C., Jansson, B. \& Archer, T. (2008). Influence of affective personality type and gender upon coping behavior, mood, and stress. Individual Differences Research, 6(3), 139-168.

Bood, S. A., Archer, T. \& Norlander, T. (2004). Affective personality in relation to general personality, self-reported stress, coping and optimism. Individual Differences Research, 2(1), 26-37.

Bradburn, N. M. (1969). The structure of psychological well-being. Chicago: IL: Aldine.

Cohen, J. (1988). Statistical power analysis for the behavioral sciences ( $2^{\text {nd }}$. ed.). Hillsdale, NJ: Erlbaum.

Costa, P. T., Jr. \& McCrae, R. R. (1992). NEO PI-R professional manual. Odessa, FL: Psychological Assessment Resources, Inc.

DeNeve, K. M. \& Cooper, H. (1998). The happy personality: A meta-analysis of 137 personality traits and subjective well-being. Psychological Bulletin, 124(2), 197-229.

Diener, E. \& Emmons, R. A. (1985). The independence of positive and negative affect. Journal of Personality and Social Psychology, 47(5), 1105-1117.

Diener, E., Lucas, R. E. \& Oishi, S. (2005). Subjective well-being: The science of happiness and life satisfaction. In C. R. Snyder \& S. J. Lopez (Eds.), Handbook of positive psychology (pp. 63-73). New York: Oxford University Press.

Diener, E., Scollon, C. N. \& Lucas, R. E. (2003). The evolving concept of subjective well-being: The multifaceted nature of happiness. Advances in Cell Aging and Gerontology, 15, 187-219.

Giacomoni, C. H. \& Hutz, C. S. (1997, July). A mensuração do bem-estar subjetivo: Escala de afeto positivo e negativo e escala de satisfação de vida [Subjective well-being assessment: Positive and Negative Affect Scale and Life Satisfaction Scale]. Paper presented at the Annual Meeting of the $26^{\text {th }}$ Interamerican Congress of Psychology, São Paulo, Brazil.

Grueber, J., Maus, I. B. \& Tamis, M. (2011). A dark side of happiness? How, when, and why happiness is not always good. Perspectives on Psychological Science, 6(3), 222-233. 
Hutz, C. S. \& Nunes, C. H. S. S. (2001). Escala Fatorial de Ajustamento Emocional/Neuroticismo [Factor Scale of Neuroticism]. São Paulo: Casa do Psicólogo.

Hutz, C. S., Bardagi, M. P., Souza, L. K. \& Sternert, F. (2009). Adaptação, validação e normatização da Escala de Satisfação de Vida [Adaptation, validation, and normatization of the Satisfaction with Life Scale]. Manuscript submitted for publication.

Joireman, J. (2004). Empathy and self-absorption paradox II: Self-rumination and self-reflection as mediators between shame, guilt, and empathy. Self and Identity, 3, 225-238.

Jose, P. E. \& Brown, I. (2008). When does the gender difference in rumination begin? Gender and age differences in the use of rumination by adolescents. Journal of Youth Adolescence, 37(2), 180-192.

Karlsson, E. \& Archer, T. (2007). Relationship between personality characteristics and affect: Gender and affective personality. Individual Differences Research, 5(1), 44-58.

Lyubomirsky, S., Caldwell, N. D. \& Nolen-Hoeksema, S. (1998). Effects of ruminative and distracting responses to depressed mood on retrieval of autobiographical memories. Journal of Personality and Social Psychology, 75(1), 166-177.

Lyubomirsky, S. \& Tkach, C. (2004). The consequences of dysphoric rumination. In C. Papageorgiou \& A. Wells (Eds.), Rumination: Nature, theory, and treatment of negative thinking in depression (pp. 21-41). Chichester, England: John Wiley \& Sons.

Lyubomirsky, S., King, L. \& Diener, E. (2005). The benefits of frequent positive affect: Does happiness lead to success? Psychological Bulletin, 131(6), 803-855.

McCrae, R. R. \& John, O. P. (1992). An introduction to the five-factor model and its applications. Journal of Personality, 60(2), 175-215.

Muris, P., Roelofs, J., Rassin, E., Franken, I. \& Mayer, B. (2005). Mediating effects of rumination and worry on the links between neuroticism, anxiety and depression. Personality and Individual Differences, 39(6), 1105-1111.

Naragon, K. \& Watson, D. (2009). Positive affectivity. In S. J. Lopez (Ed.), Encyclopedia of positive psychology
(Vol.2, pp.707-711). Malden, MA: Wiley-Blackwell Publishers.

Nolen-Hoeksema, S. (1991). Response to depression and their effects on the duration of depressive episodes. Journal of Abnormal Psychology, 100(4), 569-582.

Nolen-Hoeksema, S. \& Jackson, B. (2001). Mediator of the gender difference in rumination. Psychology of Women Quarterly, 25(1), 37-47.

Norlander, T., Bood, S. A. \& Archer, T. (2002). Performance during stress: Affective personality, age, and regularity of physical exercise. Social Behavior and Personality, 30(5), 495-508.

Norlander, T., Johansson, A. \& Bood, S, A. (2005). The affective personality: Its relation to quality of sleep, well-being and stress. Social Behavior and Personality, 33(7), 709-722.

Papageorgiou, C., \& Wells, A. (2004). Depressive rumination: Nature, theory and treatment. Chichester, England: John Wiley \& Sons.

Pavot, W. \& Diener, E. (1993). Review of the Satisfaction with Life Scale. Psychological Assessment, 5(2), 164-172.

Roberts, J. E., Gilboa, E. \& Gotlib, I. H. (1998). Ruminative response style and vulnerability to episodes of dysphoria: Gender, neuroticism, and episode duration. Cognitive Therapy and Research, 22 (4), 401-423.

Seligman, M. E. P. (2005). Positive psychology, positive prevention, and positive therapy. In C. R. Snyder \& S. J. Lopez (Eds.), The handbook of positive psychology (pp. 3-12). New York: Oxford Press.

Steel, P., Schmidt, J. \& Schultz, J. (2008). Refining the relationship between personality and subjective well-being. Psychological Bulletin, 134(1), 138-161.

Trapnell, P. D. \& Campbell, J. D. (1999). Private selfconsciousness and the five-factor model of personality: Distinguishing rumination from reflection. Journal of Personality and Social Psychology, 76(2), 284-304

Watson, D. (2005). Positive affectivity: The disposition to experience pleasurable emotional states. In C. R. Snyder \& S. J. Lopez (Eds.), Handbook of positive psychology (pp. 106-119). New York: Oxford University Press.

Watson, D., Clark, L. \& Tellegen, A. (1988). Development and validation of brief measures of positive 
and negative affect. The PANAS scale. Journal of Personality and Social Psychology, 54(6), 1063-1070.

Zanon, C. \& Hutz, C. S. (2009). Propriedades psicométricas da Escala Fatorial de Neuroticismo e do Questionário de Ruminação e Reflexão [Psychometric properties of the Factor Scale of Neuroticism and the Rumination and Reflection Questionnaire]. Avaliação Psicológica, 8(2), 279-281.
Zanon, C. \& Teixeira, M. A. (2006). Adaptação do Questionário de Ruminação e Reflexão (QRR) para estudantes universitários brasileiros [Adaptation of the Rumination and Reflection Questionnaire (RRQ) to Brazilian university students]. Interação em Psicologia, 10(1), 75-82 
